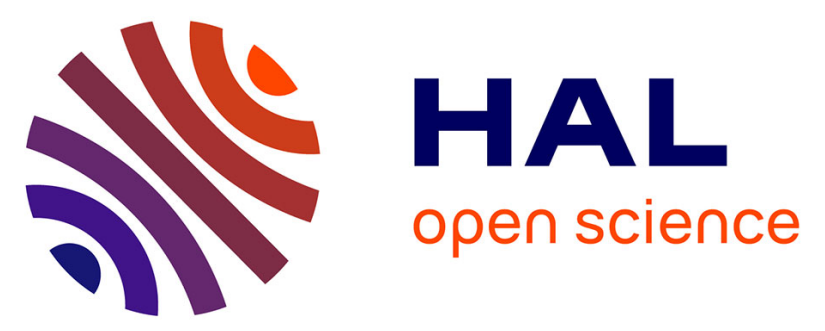

\title{
Low eicosapentaenoic acid and gamma-linolenic acid levels in breast adipose tissue are associated with inflammatory breast cancer
}

Marie Chas, Caroline Goupille, Flavie Arbion, Philippe Bougnoux, Michelle

Pinault, Marie Lise Jourdan, Stephan Chevalier, Lobna Ouldamer

\section{To cite this version:}

Marie Chas, Caroline Goupille, Flavie Arbion, Philippe Bougnoux, Michelle Pinault, et al.. Low eicosapentaenoic acid and gamma-linolenic acid levels in breast adipose tissue are associated with inflammatory breast cancer. The Breast, 2019, 45, pp.113-117. 10.1016/j.breast.2019.04.001 . hal02958753

\section{HAL Id: hal-02958753 \\ https://hal.science/hal-02958753}

Submitted on 22 Oct 2021

HAL is a multi-disciplinary open access archive for the deposit and dissemination of scientific research documents, whether they are published or not. The documents may come from teaching and research institutions in France or abroad, or from public or private research centers.
L'archive ouverte pluridisciplinaire HAL, est destinée au dépôt et à la diffusion de documents scientifiques de niveau recherche, publiés ou non, émanant des établissements d'enseignement et de recherche français ou étrangers, des laboratoires publics ou privés.

\section{(ㅇ)(1) $\$$}

Distributed under a Creative Commons Attribution - NonCommerciall 4.0 International 
Low Eicosapentaenoic acid and gamma-linolenic acid levels in breast adipose tissue are associated with inflammatory breast cancer

Marie Chas ${ }^{1,2,3}$, Caroline Goupille ${ }^{2,3}$, Flavie Arbion ${ }^{4}$, Philippe Bougnoux ${ }^{2,3,5}$, Michelle Pinault $^{2,3}$, Marie Lise Jourdan ${ }^{2,3}$, Stephan Chevalier $^{2,3}$, Lobna Ouldamer ${ }^{1,2,3}$

Authors' affiliations:

${ }^{1}$ Department of Gynecology, Centre Hospitalier Régional Universitaire de Tours, Hôpital Bretonneau. 2 boulevard Tonnellé, 37044 Tours, France; ${ }^{2}$ INSERM UMR1069 « Nutrition, Growth and Cancer », 10 boulevard Tonnellé, 37032 Tours, France; ${ }^{3}$ University of Tours, 10 boulevard Tonnellé, 37032 Tours, France; ${ }^{4}$ Department of Pathology, Centre Hospitalier Régional Universitaire de Tours. Hôpital Bretonneau, 2 boulevard Tonnellé, Tours, France ${ }^{5}$ Department of Oncology, Centre Hospitalier Régional Universitaire de Tours. Hôpital Bretonneau, 2 boulevard Tonnellé, Tours, France

\section{Corresponding author:}

Lobna Ouldamer Inserm UMR 1069

10 Boulevard Tonnellé

37032 Tours (France)

Phone: +33247366179

Fax: +332473662 26

Email: 1.ouldamer@chu-tours.fr

\section{Inflammatory breast cancer and fatty acids}




\section{ABSTRACT}

\section{Objective:}

Since it is thought that breast adipose tissue could influence breast cancer clinical presentation, we wanted to characterize specifically the relationship between breast adipose tissue fatty acid profile and Inflammatory Breast cancer (IBC).

\section{Methods:}

Two hundred thirty-four women presenting with breast cancer were managed in our centre between January 2009 and December 2011. Breast adipose tissue specimens were collected during breast surgery. We established the biochemical profile of adipose tissue fatty acids (FA) by gas chromatography and assessed whether there were differences in function of the presence of breast inflammation or not.

Results: We found that IBC was associated with decreased levels in breast adipose tissue of eicosapentaenoic acid (EPA), one of the two main polyunsaturated n-3 fatty acids (n-3 PUFA) of marine origin, but also with decreased levels of Gamma Linolenic acid (GLA). Inversely, an increase in palmitic acid levels was associated with IBC.

Conclusion: These differences in lipid content may contribute to the occurrence of breast cancer inflammation.

KEY WORDS: Adipose samples; Breast cancer; eicosapentaenoic acid; Inflammation. 


\section{Introduction}

Inflammatory breast cancer (IBC) is considered an aggressive form of locally advanced cancer. It is a rare type of breast cancer (2-5\% of all breast cancer cases) that develops rapidly, characterized by diffuse dermatologic erythema and edema making the affected breast red, swollen and tender [1]. IBC is designated as T4d in the American Joint Committee on Cancer (AJCC) Tumor, Node, Metastasis (TNM) staging system [2,3]. All of the following criteria must be met for its diagnosis: 1) Rapid onset of breast erythema, edema and/or peau d'orange, and/or warm breast, with or without an underlying palpable mass. 2) Duration of history no more than six months. 3) Erythema occupying at least one-third of the breast. 4) Histologic confirmation of invasive carcinoma. Despite IBC can be associated with any breast cancer subtypes, this is most common with hormone receptor-negative or HER2-positive disease. [4-6]. Multimodality therapy is standard for non-metastatic IBC disease and includes neoadjuvant chemotherapy followed by mastectomy and post mastectomy radiation. IBC is associated with a worse prognosis, due to higher risk of relapse and shorter survival compared to non-inflammatory disease. [4,7].

Mechanisms underlying breast inflammation remain unclear. However, strong overexpression of angiogenesis-related genes and eicosanoid-linked COX-2 enzyme, up-regulation of Rho C GTPase (involved in cytosqueletal organization or regulation of inflammatory, angiogenic factors) or abnormal E-cadherin retention despite EMT phenotype have been described to be associated with IBC [8-10].

In the breast epithelial cells are embedded within a fat environment. There is a growing interest in potential metabolites or substrates that could be released during adipose lipolysis process thereby contributing to tumor progression [11,12]. Thus, characterizing the relationship between breast adipose tissue fatty acid profile and IBC is particularly important. 
We hypothesized that a specific adipose tissue fatty acid composition may be associated to the onset of IBC. We studied the fatty acid profile of samples of breast adipose tissue and investigated whether this composition differed in relation with breast inflammation or not.

\section{MATERIALS AND METHODS}

\section{Study population}

In this retrospective study, we analyzed data of 234 consecutive women treated for an invasive breast cancer between January 2009 and December 2011 in our Breast Cancer Care unit.

Patients with invasive breast cancer treated between January 2009 and December 2011 with an available breast adipose tissue sample stored in liquid nitrogen were included in the analysis.

Patients diagnosed with ductal carcinoma in situ (DCIS) alone were excluded. Data about baseline patients' characteristics were retrieved from the electronic medical records at our Institution.

\section{Methods}

The population of patients was from Central France. Our pathologist (FA) with expertise in breast pathology reviewed the histology specimen's slides and reports.

\section{Samples details}

Samples were excised during surgery from the external (tumor-free) region of the lumpectomy or mastectomy. Samples were stored in liquid nitrogen to minimize degradation.

\section{Lipid analysis}

From $10 \mathrm{mg}$ frozen adipose samples, total lipids were extracted with $8 \mathrm{~mL}$ Methanol: Chloroform (2:1) and $2 \mathrm{~mL}$ water [13]. After vortexing and sonicating, the lower chloroform 
phase was withdrawn and evaporated under vacuum. One mg of total lipids were spotted on silica thin layer chromatography plate (Meckmillipore) and triglycerides were separated using development solvent as follows hexane:diethyl ether:glacial acetic acid 70:30:1. The

triglycerides spots were scrapped and fatty acids were directly transmethylated with $14 \%$ boron trifluoride in methanol (BF3, Fluka, St. Quentin Fallavier, France) 30 min à $100^{\circ} \mathrm{C}$. After extraction with hexane, fatty acid methyl esters (FAME) were analysed by capillary gas chromatography on a GC-2010 Plus chromatograph (Schimadzu, France) equipped with an AOC20i autosampler, an on-column injector, a flame ionization detector and a BPX70 column (60m x id 0.25mm, SGE, Courtaboeuf, France). Hydrogen was used as carrier gas at constant pressure $(130 \mathrm{kPa})$. The oven program started with initial temperature $60^{\circ} \mathrm{C}$ held for $5 \mathrm{~min}$, increased to $140^{\circ} \mathrm{C}$ (rate of $5^{\circ} \mathrm{C} / \mathrm{min}$ ) that it was held for $25 \mathrm{~min}$, increased to $145^{\circ} \mathrm{C}$ $\left(0.4^{\circ} \mathrm{C} / \mathrm{min}\right)$ held for $10 \mathrm{~min}$, increased to $180^{\circ} \mathrm{C}\left(1.5^{\circ} \mathrm{C} / \mathrm{min}\right)$ held for $10 \mathrm{~min}$, increased $190^{\circ} \mathrm{C}$ $\left(0.5^{\circ} \mathrm{C} / \mathrm{min}\right.$ ) held for $4 \mathrm{~min}$, then increased to $220^{\circ} \mathrm{C}$ (rate of $10^{\circ} \mathrm{C} / \mathrm{min}$ ) held for $6 \mathrm{~min}$. FAME were identified by comparison of their retention time with those of authentic standards (Supelco, USA). Using GCSolution software (Shimadzu, France), peaks were integrated and each fatty acid was expressed as $\%$ of total peak area. The percentage of identified peaks was superior to $96 \%$.

\section{Statistical analysis}

The categorical and numerical variables were analyzed using the Chi-square test and the Student t-test, respectively. $\mathrm{P}$ values $<0.05$ were considered to denote significant differences. Data were managed with an Excel database (Microsoft, Redmond, WA, USA) and analyzed using R 2.15 software, available online. 


\section{Results:}

Breast adipose tissue samples were obtained from 234 patients who underwent surgery at our university teaching hospital. Characteristics of the population are described in table 1. Among the 234 patients, twenty-one $(8.9 \%)$ had IBC. There were no differences in age between the two groups. Body Mass Index (BMI) was higher $\left(27.3\right.$ versus $\left.25.3 \mathrm{~kg} / \mathrm{m}^{2}, \mathrm{p}=0.05\right)$ in case of IBC when compared to women with non-inflammatory breast cancer.

Hormone receptor-negative subtypes were predominant in our population $(71 \%)$, with a marked high proportion of HER2-positive subtype when compared to non-IBC (38.1\% versus $12.2 \%)$

The more frequent fatty acids found in breast adipose tissues are presented in Table 2, according to inflammation. Significant differences were found in the fatty acid profile in adipose tissue of patients with IBC as compared to patients with non-IBC. Total saturated fatty acids (SAFA) level tended to be increased in adipose environment of IBC $(p=0.09)$ and the increase was significant $(+4.4 \%)$ for palmitic acid (16:0), the major SAFA.

No difference was observed for individual or total monounsaturated fatty acid levels.

Among PUFA, Gamma Linolenic acid (GLA) (C18 :3n-6) and Eicosapentaenoic acid (EPA) (C20:5n-3) levels were lower in patients with IBC than in patients with non-IBC, with a decrease of $17 \%$ and $25 \%$, respectively $(\mathrm{p}=0.009, \mathrm{p}=0.0003)$. There were no significant differences with respect to other FA.

\section{DISCUSSION}

The aim of this study was to evaluate whether alterations in the breast adipose tissue lipid composition are associated with IBC. We found a trend for increasing saturated FA levels, with a statistically significant increase in palmitic acid levels in case of IBC. We also 
found a significant association between low levels of EPA, and GLA in breast adipose tissue and IBC.

The aetiology of breast cancer is multifactorial and involves nutritional, endocrine and genetic factors [14]. As previously reported[4-6], we confirmed a higher prevalence of triplenegative and HER2-positive disease among cases of IBC. The molecular basis of the inflammatory process in IBC could be linked to regulation of pro-inflammatory and proangiogenic cytokines. This can be combined with pro-inflammatory eicosanoids synthesis, especially when tumors overexpress COX-2 enzyme [8]. However, adipose lipolysis during tumor progression and contribution of released components cannot be excluded [15].

Also, patients with IBC had higher BMI compared to patients with non-inflammatory disease. Moreover, obese women have higher chances of presenting with IBC $(p=0.006)$, large tumours $(p=0.038)$ and nodal involvement $(p=0.03)$ [16]. The association between adipose tissue inflammation and obesity is now well described in literature [17].

Our analysis shows that IBC is associated with increased SAFA levels. This pejorative effect of SAFA is in line with literature data describing higher specific mortality in women with breast cancer with high levels of SAFA $[18,19]$. As reported in a recent meta-analysis [20], breast cancer death was higher for women consuming diet with higher levels of saturated fat.

Fatty acid analysis showed also association between low GLA (18:3n-6) levels and IBC. In literature, anti-tumor effects by GLA enrichment remains controverted in vitro or in animal models [21-23]. Whereas anti-tumor effects can be linked to fatty acid synthase or HER2 decrease on tumor cells [24,25], major ambivalence of GLA is performed by regulating quality / quantity of eicosanoids [23]. Although it belongs to n-6 PUFA family which is rather associated to tumor promotion, GLA can be converted by cyclooxygenase (such as COX-2) 
and lipooxygenase and produce pro-inflammatory but also anti-inflammatory eicosanoids [26,27]. This is linked to its prior metabolization to gamma-linolenate $(20: 3 n-6)$ or arachidonic acid (20:4n-6). Whereas gamma-linolenate lead to 1-serie prostaglandins and 15HETrE with anti-inflammatory or anti-proliferative properties, arachidonic acid allow synthesis of 2-serie prostaglandins and leukotrienes and thromboxane. These latter support tumor growth and invasion and stimulate angiogenesis [12]. In our study, arachidonic acid level was not modified in IBC group. The impact of low level of GLA (18:3n-6) have to be elucidated but decrease of anti-inflammatory eicosanoids may be compatible with IBC.

Our findings about EPS are consistent with previous literature. A low intake of n-3 PUFA of marine origin (EPA, C20 :5n-3 and docosahexaenoic acid (DHA, C22 :6n-3)) has been associated with a high risk of recurrence. Patterson et al. showed that high dietary intake of EPA and DHA is associated with a $25 \%$ reduction of breast cancer-specific mortality [28]. Khankari et al showed that a diet enriched with n-3 PUFA with low levels of n-6 PUFA could reduce breast cancer risk [29] and increase overall survival after breast cancer treatment [14]. Low levels of EPA and DHA are also associated with higher chances of multifocal breast cancer, which is a known poor prognostic feature [31]. A pilot study of n-3 PUFA supplementation along with chemotherapy documented improved treatment outcomes in metastatic breast cancer patients. [32]. Protective effects of regimen enriched with n-3 PUFA are well documented in rodent models and are increasingly supported by evidence in humans $[33,34]$. Several molecular mechanisms, more and less interlinked, are proposed to explain the effects of n-3 PUFA. Among these it can be noticed a regulation of growth factor receptors by membrane fluidity, a regulation of gene and signal transduction via PPAR activation [35] or NF-kB, a decrease of angiogenesis [36], a regulation of immune system with decrease of inflammatory cytokines (IL-6, TNFa) or synthesis of anti-inflammatory 
EPA-derived eicosanoids (3-series prostaglandins, resolvins) at the expense of arachidonatederived eicosanoids [33,37]. As suggested above, deficiency of EPA fatty acid is compatible with inflammatory phenotype expression.

Lipid composition of adipose tissue is considered as a long term biomarker of past dietary intake of fatty acids due to its slow turn-over [38-40]. Our results suggest the possibility of a link between dietary habits and clinical presentation of breast cancer. Saturated fatty acids are particularly found in animal-derived food, butter or cheese and in vegetable oils such as palm oil. GLA can be obtained from green vegetables, walnuts, or vegetable GLA-rich primrose or borage oils. Major food sources of EPA are fatty cold-water fish/fish oil of marine origin. Endogenously synthetized fatty acids cannot be eluded, particularly for saturated fatty acids [39]. However, elongation and desaturation of PUFA remain low in humans [37] and strong correlation have been found between dietary EPA and DHA fatty acid supplements and breast adipose composition [41,42]. Thus, the low EPA level in this storage tissue could reasonably reflect a lower past intake of long chain FA of marine origin.

Since inflammation is linked to breast cancer prognosis [4,7], it is not surprising to find a similar association between lower n-3 PUFA levels and IBC. The low rate of both fatty acids in adipose tissue with potential anti-inflammatory properties could cooperate with IBC presentation, particularly whether IBC tumor overexpress COX-2. In association with findings of other studies, these present results reinforce the possibility of a link between dietary habits and the clinical expression of breast cancer. This hypothesis needs to be confirmed prospectively and with a study of dietary intervention.

Financial support: ARD2020, INSERM,Univ 
We thank Redah Rafiq and Violetta Guerin for their technical support

\section{Conflict of interest statement:}

We declare that we have no conflict of interest

\section{References}

1. Robertson FM, Bondy M, Yang W, Yamauchi H, Wiggins S, Kamrudin S, et al. Inflammatory breast cancer: the disease, the biology, the treatment. CA Cancer J Clin. 2010 Dec;60(6):351-75.

2. Fouad TM, Barrera AMG, Reuben JM, Lucci A, Woodward WA, Stauder MC, et al. Inflammatory breast cancer: a proposed conceptual shift in the UICC-AJCC TNM staging system. Lancet Oncol. 2017 Apr;18(4):e228-32.

3. Sinn H-P, Helmchen B, Wittekind CH. [TNM classification of breast cancer: changes and comments on the 7th edition]. Pathol. 2010 Sep;31(5):361-6.

4. Dawood S, Ueno NT, Valero V, Woodward WA, Buchholz TA, Hortobagyi GN, et al. Differences in survival among women with stage III inflammatory and noninflammatory locally advanced breast cancer appear early: a large population-based study. Cancer. 2011 May 1;117(9):1819-26.

5. Van Laere SJ, Van den Eynden GG, Van der Auwera I, Vandenberghe M, van Dam P, Van Marck EA, et al. Identification of cell-of-origin breast tumor subtypes in inflammatory breast cancer by gene expression profiling. Breast Cancer Res Treat. 2006 Feb;95(3):243-55.

6. Bertucci F, Finetti P, Rougemont J, Charafe-Jauffret E, Cervera N, Tarpin C, et al. Gene expression profiling identifies molecular subtypes of inflammatory breast cancer. Cancer Res. 2005 Mar 15;65(6):2170-8.

7. Schlichting JA, Soliman AS, Schairer C, Schottenfeld D, Merajver SD. Inflammatory and non-inflammatory breast cancer survival by socioeconomic position in the Surveillance, Epidemiology, and End Results database, 1990-2008. Breast Cancer Res Treat. 2012 Aug;134(3):1257-68.

8. Van der Auwera I, Van Laere SJ, Van den Eynden GG, Benoy I, van Dam P, Colpaert $\mathrm{CG}$, et al. Increased angiogenesis and lymphangiogenesis in inflammatory versus noninflammatory breast cancer by real-time reverse transcriptase-PCR gene expression quantification. Clin Cancer Res Off J Am Assoc Cancer Res. 2004 Dec 1;10(23):7965-71.

9. van Golen KL, Wu ZF, Qiao XT, Bao L, Merajver SD. RhoC GTPase overexpression modulates induction of angiogenic factors in breast cells. Neoplasia N Y N. 2000 Oct;2(5):418-25.

10. Van den Eynden GG, Van der Auwera I, Van Laere S, Colpaert CG, van Dam P, Merajver S, et al. Validation of a tissue microarray to study differential protein expression in inflammatory and non-inflammatory breast cancer. Breast Cancer Res Treat. 2004 May;85(1):13-22.

11. Balaban S, Shearer RF, Lee LS, van Geldermalsen M, Schreuder M, Shtein HC, et al. Adipocyte lipolysis links obesity to breast cancer growth: adipocyte-derived fatty acids drive breast cancer cell proliferation and migration. Cancer Metab. 2017;5:1.

12. Wang YY, Attané C, Milhas D, Dirat B, Dauvillier S, Guerard A, et al. Mammary adipocytes stimulate breast cancer invasion through metabolic remodeling of tumor cells. JCI Insight. 2017 Feb 23;2(4):e87489.

13. Folch J, Lees M, Sloane Stanley GH. A simple method for the isolation and purification of total lipides from animal tissues. J Biol Chem. 1957 May;226(1):497-509.

14. Delort L, Rossary A, Farges M-C, Vasson M-P, Caldefie-Chézet F. Leptin, adipocytes 
and breast cancer: Focus on inflammation and anti-tumor immunity. Life Sci. 2015 Nov 1;140:37-48.

15. Howe LR, Subbaramaiah K, Hudis CA, Dannenberg AJ. Molecular pathways: adipose inflammation as a mediator of obesity-associated cancer. Clin Cancer Res Off J Am Assoc Cancer Res. 2013 Nov 15;19(22):6074-83.

16. Boivin L, Diguisto C, Chas M, Bédouet L, Etienne C, Arbion F, et al. [Outcomes of patients with breast cancer in function of their body mass index]. Gynecol Obstet Fertil Senol. 2017 Apr;45(4):215-23.

17. Wensveen FM, Valentić S, Šestan M, Turk Wensveen T, Polić B. The "Big Bang" in obese fat: Events initiating obesity-induced adipose tissue inflammation. Eur J Immunol. 2015 Sep;45(9):2446-56.

18. Jain M, Miller AB, To T. Premorbid diet and the prognosis of women with breast cancer. J Natl Cancer Inst. 1994 Sep 21;86(18):1390-7.

19. Zhang S, Folsom AR, Sellers TA, Kushi LH, Potter JD. Better breast cancer survival for postmenopausal women who are less overweight and eat less fat. The Iowa Women's Health Study. Cancer. 1995 Jul 15;76(2):275-83.

20. Brennan SF, Woodside JV, Lunny PM, Cardwell CR, Cantwell MM. Dietary fat and breast cancer mortality: A systematic review and meta-analysis. Crit Rev Food Sci Nutr. 2017 Jul 3;57(10):1999-2008.

21. Rose DP, Connolly JM, Liu XH. Effects of linoleic acid and gamma-linolenic acid on the growth and metastasis of a human breast cancer cell line in nude mice and on its growth and invasive capacity in vitro. Nutr Cancer. 1995;24(1):33-45.

22. Pham H, Vang K, Ziboh VA. Dietary gamma-linolenate attenuates tumor growth in a rodent model of prostatic adenocarcinoma via suppression of elevated generation of PGE(2) and 5S-HETE. Prostaglandins Leukot Essent Fatty Acids. 2006 Apr;74(4):271-82.

23. Wang $\mathrm{X}$, Lin $\mathrm{H}, \mathrm{Gu} \mathrm{Y}$. Multiple roles of dihomo- $\gamma$-linolenic acid against proliferation diseases. Lipids Health Dis. 2012 Feb 14;11:25.

24. Menendez JA, Colomer R, Lupu R. Inhibition of fatty acid synthase-dependent neoplastic lipogenesis as the mechanism of gamma-linolenic acid-induced toxicity to tumor cells: an extension to Nwankwo's hypothesis. Med Hypotheses. 2005;64(2):337-41.

25. Menendez JA, Vellon L, Colomer R, Lupu R. Effect of gamma-linolenic acid on the transcriptional activity of the Her-2/neu (erbB-2) oncogene. J Natl Cancer Inst. 2005 Nov 2;97(21):1611-5.

26. Kapoor R, Huang Y-S. Gamma linolenic acid: an antiinflammatory omega-6 fatty acid. Curr Pharm Biotechnol. 2006 Dec;7(6):531-4.

27. Xu Y, Qian SY. Anti-cancer activities of $\omega-6$ polyunsaturated fatty acids. Biomed J. 2014 Jun;37(3):112-9.

28. Patterson RE, Flatt SW, Newman VA, Natarajan L, Rock CL, Thomson CA, et al. Marine fatty acid intake is associated with breast cancer prognosis. J Nutr. 2011 Feb;141(2):201-6.

29. Khankari NK, Bradshaw PT, Steck SE, He K, Olshan AF, Shen J, et al. Polyunsaturated fatty acid interactions and breast cancer incidence: a population-based casecontrol study on Long Island, New York. Ann Epidemiol. 2015 Dec;25(12):929-35.

30. Khankari NK, Bradshaw PT, Steck SE, He K, Olshan AF, Shen J, et al. Dietary intake of fish, polyunsaturated fatty acids, and survival after breast cancer: A population-based follow-up study on Long Island, New York. Cancer. 2015 Jul 1;121(13):2244-52.

31. Ouldamer L, Goupille C, Vildé A, Arbion F, Body G, Chevalier S, et al. N-3 Polyunsaturated Fatty Acids of Marine Origin and Multifocality in Human Breast Cancer. PloS One. 2016;11(1):e0147148.

32. Bougnoux P, Hajjaji N, Ferrasson MN, Giraudeau B, Couet C, Le Floch O. Improving 
outcome of chemotherapy of metastatic breast cancer by docosahexaenoic acid: a phase II trial. Br J Cancer. 2009 Dec 15;101(12):1978-85.

33. Liu J, Ma DWL. The role of n-3 polyunsaturated fatty acids in the prevention and treatment of breast cancer. Nutrients. 2014 Nov 18;6(11):5184-223.

34. Bougnoux P, Hajjaji N, Maheo K, Couet C, Chevalier S. Fatty acids and breast cancer: sensitization to treatments and prevention of metastatic re-growth. Prog Lipid Res. 2010 Jan;49(1):76-86.

35. Wannous R, Bon E, Mahéo K, Goupille C, Chamouton J, Bougnoux P, et al. PPAR $\beta$ mRNA expression, reduced by n-3 PUFA diet in mammary tumor, controls breast cancer cell growth. Biochim Biophys Acta. 2013 Nov;1831(11):1618-25.

36. Kornfeld S, Goupille C, Vibet S, Chevalier S, Pinet A, Lebeau J, et al. Reducing endothelial NOS activation and interstitial fluid pressure with n-3 PUFA offset tumor chemoresistance. Carcinogenesis. 2012 Feb;33(2):260-7.

37. Calder PC. Omega-3 polyunsaturated fatty acids and inflammatory processes: nutrition or pharmacology? Br J Clin Pharmacol. 2013 Mar;75(3):645-62.

38. Arab L. Biomarkers of fat and fatty acid intake. J Nutr. 2003 Mar;133 Suppl 3:925S 932S.

39. Hodson L, Skeaff CM, Fielding BA. Fatty acid composition of adipose tissue and blood in humans and its use as a biomarker of dietary intake. Prog Lipid Res. 2008 Sep;47(5):348-80.

40. Strawford A, Antelo F, Christiansen M, Hellerstein MK. Adipose tissue triglyceride turnover, de novo lipogenesis, and cell proliferation in humans measured with $2 \mathrm{H} 2 \mathrm{O}$. Am J Physiol Endocrinol Metab. 2004 Apr;286(4):E577-88.

41. Fabian CJ, Kimler BF, Phillips TA, Nydegger JL, Kreutzjans AL, Carlson SE, et al. Modulation of Breast Cancer Risk Biomarkers by High-Dose Omega-3 Fatty Acids: Phase II Pilot Study in Postmenopausal Women. Cancer Prev Res Phila Pa. 2015 Oct;8(10):922-31.

42. Yee LD, Lester JL, Cole RM, Richardson JR, Hsu JC, Li Y, et al. Omega-3 fatty acid supplements in women at high risk of breast cancer have dose-dependent effects on breast adipose tissue fatty acid composition. Am J Clin Nutr. 2010 May;91(5):1185-94. 
Table 1: Demographic and histological characteristics

\begin{tabular}{|c|c|c|c|c|c|c|c|}
\hline & \multicolumn{2}{|c|}{$\begin{array}{c}\text { All patients } \\
\mathbf{n}=\mathbf{2 3 4}\end{array}$} & \multicolumn{2}{|c|}{$\begin{array}{l}\text { No breast inflammation } \\
\qquad n=213\end{array}$} & \multicolumn{2}{|c|}{$\begin{array}{c}\text { Breast inflammation } \\
n=21\end{array}$} & \multirow[t]{2}{*}{$p$} \\
\hline & Mean or $\mathrm{n}(\%)$ & Range & Mean or $\mathrm{n}(\%)$ & Range & Mean or $\mathrm{n}(\%)$ & Range & \\
\hline Age (years) & 56.15 & $28-89$ & 55.8 & $28-89$ & 59 & $37-83$ & 0.45 \\
\hline Post menopausal & $140(59.8 \%)$ & & $87(40.8 \%)$ & & $5(23.8 \%)$ & & 1 \\
\hline HRT & $37(26.4 \%)$ & & $33(37.9 \%)$ & & $4(19 \%)$ & & 0.74 \\
\hline $\operatorname{BMI}\left(\mathrm{Kg} / \mathrm{m}^{2}\right)$ & 25.5 & $13-41$ & 25.3 & $13-41$ & 27.3 & $22-36$ & 0.05 \\
\hline BMI categories & & & & & & & 0.11 \\
\hline -Underweight & $11(4.7 \%)$ & & $11(5.2 \%)$ & & $0(0 \%)$ & & \\
\hline -Normal & $101(43.2 \%)$ & & $96(45.1 \%)$ & & $5(23.8)$ & & \\
\hline -Overweight & $68(29 \%)$ & & $60(28.2 \%)$ & & $8(38.1 \%)$ & & \\
\hline -Obese & $46(19.6 \%)$ & & $39(18.3 \%)$ & & $7(33.3 \%)$ & & \\
\hline - Unknown & $8(3.4 \%)$ & & $7(3.2 \%)$ & & $1(4.7 \%)$ & & \\
\hline Histological size (mm) & 26.5 & $3-210$ & 25.2 & $3-210$ & 42 & $5-70$ & 0.52 \\
\hline Molecular phenotype & & & & & & & 0.002 \\
\hline Luminal A & $73(31.2 \%)$ & & $72(33.8 \%)$ & & $1(4.8 \%)$ & & \\
\hline Luminal B & $64(27.3 \%)$ & & $59(27.7 \%)$ & & $5(23.8 \%)$ & & \\
\hline Triple negative & $63(26.9 \%)$ & & $56(26.3 \%)$ & & $7(33.3 \%)$ & & \\
\hline HER2 & $34(14.5 \%)$ & & $26(12.2 \%)$ & & $8(38.1 \%)$ & & \\
\hline Grade & & & & & & & 0.34 \\
\hline -Grade 1 & $22(9.4 \%)$ & & $21(9.8 \%)$ & & $1(4.7 \%)$ & & \\
\hline -Grade 2 & $100(42.7 \%)$ & & $93(43.7 \%)$ & & $7(33.3 \%)$ & & \\
\hline -Grade 3 & $109(46.6 \%)$ & & $96(45.1 \%)$ & & $13(61.9 \%)$ & & \\
\hline -Unknown & $3(1.3 \%)$ & & $3(1.4 \%)$ & & $0(0 \%)$ & & \\
\hline Lymphovascular invasion & $70(29.9 \%)$ & & $62(29.1 \%)$ & & $8(38.1 \%)$ & & 0.12 \\
\hline Axillary positive LN & $97(41.4 \%)$ & & $86(40.4 \%)$ & & $11(52.4 \%)$ & & 0.16 \\
\hline Multifocality & $57(24.3 \%)$ & & $49(23 \%)$ & & $8(38.1 \%)$ & & 0.16 \\
\hline
\end{tabular}


Table 2: Gas chromatography assessment of fatty acid composition of breast adipose tissue according to breast inflammation

\begin{tabular}{|c|c|c|c|c|c|c|}
\hline \multirow{2}{*}{ Fatty acid } & & \multicolumn{2}{|c|}{ No breast inflammation } & \multicolumn{2}{|c|}{ Breast inflammation } & \multirow[b]{2}{*}{$p$} \\
\hline & & Mean* & Range & Mean & Range & \\
\hline \multicolumn{7}{|l|}{ Saturates } \\
\hline Myristic acid & $14: 0$ & 3.20 & $1.65-5.25$ & 3.29 & $2.59-4.0$ & 0.38 \\
\hline Palmitic acid & $16: 0$ & 22.93 & $16.71-28.8$ & 23.89 & $20.85-26.12$ & 0.007 \\
\hline \multirow[t]{2}{*}{ Stearic acid } & $18: 0$ & 5.48 & $1.99-8.33$ & 5.44 & $3.04-8.57$ & 0.88 \\
\hline & Total SFA & 32.53 & 23.42-40.62 & 33.55 & 28.82-38.58 & 0.09 \\
\hline \multicolumn{7}{|l|}{ Monounsaturates } \\
\hline Myristoleic acid & $14: 1$ & 0.27 & $0.01-0.56$ & 0.27 & $0.12-0.51$ & 0.90 \\
\hline Palmitoleic acid & $16: 1$ & 3.67 & $1.3-8.45$ & 3.47 & $1.09-7.49$ & 0.56 \\
\hline Oleic acid (OA) & $18: 1 \mathrm{n}-9 \mathrm{c}$ & 43.5 & $36.59-50.57$ & 43.3 & $37.62-47.26$ & 0.73 \\
\hline \multirow[t]{2}{*}{ Vaccenic acid } & $18: 1 \mathrm{n}-7 \mathrm{c}$ & 1.94 & $1.39-3.75$ & 1.93 & $1.25-3.39$ & 0.93 \\
\hline & Total MUFA & 50.69 & 43.42-59.59 & 50.22 & 42.02-55.94 & 0.57 \\
\hline \multicolumn{7}{|l|}{ Polyunsaturates } \\
\hline Linoleic acid (LA) & $18: 2 n-6 c$ & 11.02 & $5.97-21.0$ & 10.72 & $6.27-18.08$ & 0.66 \\
\hline Gamma Linolenic acid (GLA) & $18: 3 n-6$ & 0.05 & $0.02-0.10$ & 0.03 & $0.02-0.07$ & 0.009 \\
\hline \multirow[t]{2}{*}{ Arachidonic acid (AA) } & $20: 4 n-6$ & 0.38 & $0.15-1.01$ & 0.36 & $0.16-0.63$ & 0.43 \\
\hline & Total n-6 & 12.21 & $6.94-22.68$ & 11.92 & 7.35-18.59 & 0.67 \\
\hline Alpha Linolenic acid (ALA) & $18: 3 n-3$ & 0.60 & $0.20-1.20$ & 0.59 & $0.30-1.30$ & 0.86 \\
\hline Eicosapentaenoic acid (EPA) & $20: 5 n-3$ & 0.09 & $0.02-0.31$ & 0.07 & $0.03-0.10$ & 0.0003 \\
\hline Docosapentaenoic acid (DPA) & $22: 5 n-3$ & 0.25 & $0.05-0.52$ & 0.25 & $0.07-0.44$ & 0.99 \\
\hline \multirow[t]{2}{*}{ Docosahexaenoic acid (DHA) } & $22: 6 n-3$ & 0.21 & $0.03-0.54$ & 0.19 & $0.05-0.42$ & 0.31 \\
\hline & Total n-3 & 1.19 & $0.60-2.15$ & 1.13 & $0.65-1.83$ & 0.43 \\
\hline$n-6 / n-3$ & $n-6 / n-3$ & 10.85 & $5.49-27.08$ & 10.97 & 6.33-18.97 & 0.88 \\
\hline
\end{tabular}

* expressed as \% area 